\title{
Maqasid Al-Shariah as a Parameter in International Treaty
}

\author{
Mohd Afandi Salleh \\ Universiti Sultan Zainal Abidin \\ Kuala Terengganu,Malaysia \\ afandisalleh@gmail.com \\ Mohd Lotpi Mohd Yusob \\ Universiti Sultan Zainal Abidin \\ Kuala Terengganu,Malaysia
}

\author{
Abdul Majid Tahir Mohamed \\ Universiti Sultan Zainal Abidin \\ Kuala Terengganu,Malaysia \\ Fazidatul Aida Mat Yazid \\ Universiti Sultan Zainal Abidin \\ Kuala Terengganu,Malaysia
}

\begin{abstract}
Generally the main essence of the Maqasid alShariah (objectives of Islamic Law) is to avoid the evil and uphold the public interest. In the present Westphalia state system, it is inevitable for the Islamic countries to engage with the international treaty. However, there are several provisions in the international treaty, whether bilateral or multilateral which may not commensurate with the Maqasid al-Shariah. Malaysia as an Islamic country that is incline to uphold the principles of Shariah, may want to ensure that international treaty, will be observed and not contradicted with the principles of Maqasid al-Shariah. The paper attempts to examine the essence of Maqasid al-Shariah and it roles in international treaty. In this regard, it studies the Convention on the Elimination of All Forms of Discrimination against Women (CEDAW) in the light of Maqasid al-Shariah. The aim of the paper is to provide and suggest the Maqasid al-Shariah as a new parameter to be observed by Malaysia before giving the consent to be bound by any international treaty.
\end{abstract}

Keywords-maqasid al-syariah; cedaw; women rights; human rights; fundamental freedom; islamic law; malaysia)

\section{INTRODUCTION}

"No one is above the law" is one wisdom that ratifies that law is very powerful and have spirit to control and guide people. It shows that the substance of law is not a mere plain word without spirit. Any law is made with their own reasons and purposes. It is like for example in Islamic law, as stated in its objectives, which is to be achieved by the human being, and blessed by the God.Islamic law is an importat part of the religion has set out many regulations regarding many aspects of life including human rights. Some of the divine regulations are comprehended of its objective but there are also some others that require the deep thinking or long explanation and also detail research in order to understand their objective. We recognize certain objectives of the divine injunctions intended by the lawgiver by the research, translation and deduction made by the Islamic scholars.

The objective of Islamic law or Maqasid al-Shariahis very important in the eye of Islamic scholars in understanding and studying the legal text. They even have deduced some indispensible objectives which engaged to the divine sanction and these objectives have been imperative parameter for them in issuing legal decree through ijtihad. In addition, these objectives also could be a parameter, not only for the individual scholar, but for the government in producing the national and international policy. By observing Maqasid al-Shariah, the government of Malaysia may protect the interest of Islam as a religion of federation as stated in Article 3 of Federal Constitution and Muslim as a core and dominant citizen by ensuring the international treaties and policies that our country ratify and set up is not in contradiction with Islamic law. This research is made to examine the essence of the Maqasid al-Shariah and its role in Malaysia's international treaty and foreign policy making process.

\section{MAQASID AL SHARIAH AND MALAYSIA FOREIGN POLICY}

In order to set up a foreign policy a state will take into consideration all major factors and effects that may cause or be caused by the foreign policy which directly will create international relations with other state. A state including Malaysia normally will have their own national interest for example, economical, geographical, historical, social and political as a determinant in shaping their foreign policy and also in ratifying international treaties. Religion is often being taken into consideration, sometimes being neglected or contradicted by the international treaties. This research is conducted to find out whether Malaysia includes religion as one of the determining factor as they set up an international policy and to suggest that Maqasid al-Shariah being observed.

In addition, a foreign policy is not made instantly. It will go through a making process so that it will meet its formulating purpose. All vital interest will be taken into consideration and all responsible bodies will have opportunity to review the policy. However, it is unsure what parameter the state is using in formulating a foreign policy. A well set up parameter is the best to ensure that each and every time Malaysia wants to develop a foreign policy or to 
ratify an international treaty the parameter being followed. As an Islamic country, it is proportionate to Malaysia to apply Maqasid al-Shariahas a parameter in ratifying international treaties and also making a foreign policy.

Theword Maqasid al-Shariahis derived from two Arabic word that are maqasid and al-shariah. Maqasid is a plural word which means the aims [1], purposes or goals [2]. Meanwhile al-Shariah means what is prescribed by Allah S.W.T for His creation in the form of religious duty. When the words Maqasid and al-Shariah are combined then it connotes whatever objectives which are aimed to be achieved by Al-Quran and al-Sunnah through instructions, prohibitions and permissions [3]. Maqasid of the Islamic law are the objectives or purposesbehind Islamic rulings [2] Al-Shatibi in his famous book Al Muwafaqat Fi Usul AlShariah chaterised maslahah as principle objectives shariah and placed a great emphasis on the objectives of maqasid alshariah [4] and from as comes from interest of public (masalih al-ibad) which creates maqasid al-syariah [5].

There are 3 phenomenal types of Maqasid al-Shariah as introduced by Imam al-Haramayn al-Juwayni [6] that are al-Maqasid al-Dhoruriyyah(the essential objectives), alMaqasid al-Hajiyyah (the complementary objectives) and al-Maqasid al-Tahsiniyyah (the embellishment objectives). This categorization is unequivocally embraced and accepted by the Muslim jurists and becomes the focal point for them in discussing Maqasid al-Shariah. The essential objectives mean the aims which are to be achieved for the religious and material well-being of individual where otherwise the life will be in chaotic and destructive in this world and thereafter. The essential are matters on which the religion and worldly affairs of the people are depend upon and the neglect will lead to total disruption and in order to safeguard this it must be taken by all individual or government authorities [4].

Whereas the complementary objectives mean the aims to remove hardship and severity on life in which such hardship and severity are not to the extent of putting the life in chaotic and destructive mode. There are many examples of of al-hajiyyat such as legal excuses (rukhsah) in ibadah for travellers and sick person and also basic permissibility (ibahah) regarding victuals ang hunting [4]. The embellishment objectives aim to beautify and refine the customs and conducts of the people. The disappearance of tahsiniyyat may not interrupt the normal life but might lead to the lack of comfort in life [4].

Maqasid al-Shariah revolves around the five principles or objectives namely protection of religion, life, intellect, lineage and property [6]. Some scholars said that these objectives are the extended categorization for the Maqasid al-Dhoruriyyah. While some others said that these five principles are actually the methodology to find and establish the Maqasid al-Dhoruriyyah.
The said five principles are critically and widely examined by classical and contemporary scholars. They said that these principles are not exhaustive since there are many essential (dhoruriyyah) aspects which need to be protected and become an integral part of the objectives of Shariah. For instance,in the protection of dignity where this aspect becomes the main objective where it is protected through the divine ruling when the false accusation (al-qazf) is considered as a major sin and serious offence. However, the prominent maqasid scholar Sheikh TohirIbnuA'shur does not regard this protection of dignity as a Maqasid alDhoruriyyah because in his opinion this aspect does not reach the level of dhoruriyyah. In his opinion, he restricted the understanding on dhoruriyyah to the physical, sensible and visible aspect only where the life is depending on it. It means the dignity is not included in such understanding[3].

Although the protection of the dignity may not be included because of the said reason, but it is still argued that the said five objectives of Shariah are not exhaustive since there are many dhoruriyyah or essential aspects that need to be protected as promoted by Al-Quran and al-Sunnah directly and impliedly. Among others is the protection on the people's freedom, the protection to get the equal status before the law and others.

Basically, it is submitted that the said five objectives can be a basic guideline which is inclusive by nature in term of interpretation. For example the protection of dignity may be included under the protection of lineage because one of the wisdoms behind the divine ruling on qazf is also to cleanse the one's lineage which is one of the main five objectives as abovementioned. The five objectives will be a comprehensive and holistic guideline in any matter which is sought not to infringe the Shariah or Maqasid al-Shariah. Al-Quran and hadith have shown how the divine ruling protects the five objectives as follows: Punishment of apostasy is to protect the religion, Ruling on qisas as a mechanism to protect life, Punishment on adultery as a tool to protect lineage, Punishment on theft as a way to protect property, Punishment on drinking liquor to protect intellect.

However, contemporary classifications have divided maqasid into three levels, general, specific and partial maqasid. Later the scholars also expanded the maqasid into wider scope of people includes, community, nations or humanity in general [4]. The widen scope of people and classifications of maqasid make it easier for a government to follow the principles of Islamic law in formulating their national and international policies.

Therefore, it is unquestionable to say that the five objectives besides it is essential to be protected it also can be a very beneficial parameter for the government who intends to uphold Islamic value in making any ruling or foreign policy. The five objectives also will be also very 
useful for the government in dealing with the international matters. As a government it has to deal and engage with its neighbour and international community. This situation sometimes requires it to conclude the agreement or treaty with the neighbour and international community. However the international treaty will always not guarantee the protection of Shariah as intended by Islamic government in internal governmental policy.

International law is generally defined as a set of rules that regulate relations between states. International law regulates the foreign policy of states. Foreign policy in this sense is defined as the general objectives that guide the activities and relationships of one state in its interactions with other states [7]. Foreign policy is formulated in order to conduct international relations between states. International law is based for a country in order to develop their foreign policy.

Foreign policy basically is the way a state creates international relations with other states. Foreign policy is one of the international treaties. A state will be a member of organization or association altogether with other state. For example, Malaysia has being a member to various organization involving different states in this world. These international relations create by ratifying international treaties or making foreign policy which intended to be met with the intention of the organization.

A state in making a foreign policy will take into consideration many vital factors like economy and politics but not includes religion. This is because from beginning religion is being separated from the government. Many international law and treaties are made without taking religion into considerations. However, Malaysia is an Islamic state with Islam as the religion of federation should take religion into consideration in foreign policy making process this is because Islamic law acts as a safeguard as we ratify the international treaty.

Here, some treaty may give benefit to the country while some others may not. Even for some international treaty it clearly clashes with the Shariah. When it contradicts Shariah, the Islamic countries may just reject it. For instance the issue which involves the freedom to change religion where Article 18 of Universal Declaration of Human Rights provides that:

"Everyone has the right to freedom of thought, conscience and religion; this right includes freedom to change his religion or belief, and freedom, either alone or in community with others and in public or private, to manifest his religion or belief in teaching, practice, worship and observance".

Besides Article 18 of International Covenant on Civil and Political Right provides the more detail insight when it says, Everyone shall have the right to "freedom of thought, conscience and religion. This right shall include freedom to have or to adopt a religion or belief of his choice, and freedom, either individually or in community with others and in public or private, to manifest his religion or belief in worship, observance, practice and teaching; No one shall be subject to coercion which would impair his freedom to have or to adopt a religion or belief of his choice; Freedom to manifest one's religion or beliefs may be subject only to such limitations as are prescribed by law and are necessary to protect public safety, order, health, or morals or the fundamental rights and freedoms of others; The States Parties to the present Covenant undertake to have respect for the liberty of parents and, when applicable, legal guardians to ensure the religious and moral education of their children in conformity with their own convictions."

Basically the freedom of religion is guaranteed in Islam but the freedom to change religion by a Muslim is not tolerated by Islam. This is one of the main things that seems not suited to the Islamic principles.

However, sometimes international treaty seems not infringing directly the principles of Shariah but the objectives of Shariah tend to be neglected. This situation may invite the said five objectives of Maqasid al-Shariah to come to the picture filtering and scrutinizing the international treaty. For example Article 21 of The Convention on the Rights of the Child recognized and allowed the system of child adoption by saying that:

"States Parties that recognize and/or permit the system of adoption shall ensure that the best interests of the child shall be the paramount consideration and they shall: (a) Ensure that the adoption of a child is authorized only by competent authorities who determine, in accordance with applicable law and procedures and on the basis of all pertinent and reliable information, that the adoption is permissible in view of the child's status concerning parents, relatives and legal guardians and that, if required, the persons concerned have given their informed consent to the adoption on the basis of such counselling as may be necessary; (b) Recognize that inter-country adoption may be considered as an alternative means of child's care, if the child cannot be placed in a foster or an adoptive family or cannot in any suitable manner be cared for in the child's country of origin; (c) Ensure that the child concerned by inter-country adoption enjoys safeguards and standards equivalent to those existing in the case of national adoption; (d) Take all appropriate measures to ensure that, in inter-country adoption, the placement does not result in improper financial gain for those involved in it; (e) Promote, where appropriate, the objectives of the present article by concluding bilateral or multilateral arrangements or agreements, and endeavour, within this framework, to ensure that the placement of the child in another country is carried out by competent authorities or organs".

However this is a blanket recognition and permission without considering the issue of the religion of the child and 
the potential adopting parents. There will be a problem when the potential adopting parent is non-Muslim and the child is from the Muslim family. This situation may affect the sensitivity of the Muslim society with regard to the dignity of Islam in Muslim majority country. The article is superficially commensurate with Islam on the issue of permissibility of child adoption but by giving the blanket permission then it may affect one of the objectives of Shariah that is protection of religion." However, sometimes it seems not infringing directly the principles of Shariah but the objectives of Shariah tend to be neglected. This situation may invite the said five objectives of Maqasid al-Shariah to come to the picture filtering and scrutinizing the international treaty.

The treaty is in futile if it does not serve the objectives of Shariah. Therefore in order to avoid treaty from becoming non-Shariah or Maqasid compliance, we have to screen it through the said five objectives. The five objectives will be put as a parameter to filter and screen the international treaty in order to prevent the Islamic countries from giving consent to the treaty that is potentially disregard Shariah and its objectives.

If the treaty clearly infringes the objectives of Shariah, then it may affect the governmental policy of Islamic countries that tends to uphold Shariah value and it may affect the people because the protection of religion, life, intellect, lineage and property are not secured. In other words, the international treaty which is related to the religion, life, intellect, lineage and property must not consist of any substance which may distract the elements that protect those five things respectively.

\section{MALAYSIA AND CEDAW}

Malaysia has its own way in setting up a foreign policy but still it is uncertain whether religion is includes. Malaysia ratifies several international treaties as to accommodate the law of the nation and also to show support to the international treaties. As in human right United Nation Declaration of Human Right (UDHR) is the essential one.

It is disputed by the scholars to what extent religion especially Islam being ratifies in decision making process of this declaration. The disputes bring us to variety of opinion among scholars. Later Malaysia ratifies Convention on the Elimination of All Forms of Discrimination against Women (CEDAW). CEDAW intended to protect women from all discrimantion either by government or in marriage.

Article 1 defines what is understood as discrimination, clarifying that it includes:

"... Any distinction, exclusion or restriction made on the basis of sex which has the effect or purpose of impairingor nullifying the recognition, enjoyment or exercise by wome, irrespetive of their marital status, on a basis of equality of men and women, of humans rights and fundamental freedoms in the political, economic, social, cultural, civil or any other field".

CEDAW is one that cause controversial and chaos to almost all states. This is because CEDAW appears to be the most sensitive international human right treaty ever formulated and adopted by the international communityand attracts the highest number of comments from scholars and states. Some countries who ratifies set up a reservations to the articles in the CEDAW. Many of them claims that articles in CEDAW are too sensitive as to some culture and religion escpecially it is in conflict with the basic practice of the Islamic Family Law. In addition, the basic concept of the universality of women's right is the most crucial issue that exist in the adoption process of CEDAW.

Malaysia ratifies this Convention on the Elimination of All Forms of Discrimination Against Women in 1995 with reservations to some of its provisions. The original reservatioms read as follow "the Government Of Malaysia declares that malaysia's accession is subject to the understanding that the provisions of the Convention do not conflict with the provisions of the Islamic Shariah Law and the Federal Constitution Of Malaysia. With regards thereto, further, the Government Of Malaysia does not consider itself bound by the provisions of articles 2(f), 5(a), 7(b), 9 and 16 of the aforessaid Convention".

Artcle 2 (f) of the CEDAW reads as "To take all appropriate measures, including legislation, to modify or abolish existing laws, regulations, customs and practices which constitute discrimination against women"

Article 5 reads as "States Parties shall take all appropriate measures: (a) To modify the social and cultural patterns of conduct of men and women, with a view to achieving the elimination of prejudices and customary and all other practices which are based on the idea of the inferiority or the superiority of either of the sexes or on stereotyped roles for men and women;"

Article 7 reads as "States Parties shall take all appropriate measures to eliminate discrimination against women in the political and public life of the country and, in particular, shall ensure to women, on equal terms with men, the right (b) To participate in the formulation of government policy and the implementation thereof and to hold public office and perform all public functions at all levels of government;"

Article 9 reads as "First. States Parties shall grant women equal rights with men to acquire, change or retain their nationality. They shall ensure in particular that neither marriage to an alien nor change of nationality by the husband during marriage shall automatically change the nationality of the wife, render her stateless or force upon her the nationality of the husband. Second, States Parties shall 
grant women equal rights with men with respect to the nationality of their children."

Article 16 reads as "Firs, States Parties shall take all appropriate measures to eliminate discrimination against women in all matters relating to marriage and family relations and in particular shall ensure, on a basis of equality of men and women:

The same right to enter into marriage; The same right freely to choose a spouse and to enter into marriage only with their free and full consent; The same rights and responsibilities during marriage and at its dissolution; The same rights and responsibilities as parents, irrespective of their marital status, in matters relating to their children; in all cases the interests of the children shall be paramount; The same rights to decide freely and responsibly on the number and spacing of their children and to have access to the information, education and means to enable them to exercise these rights; The same rights and responsibilities with regard to guardianship, wardship, trusteeship and adoption of children, or similar institutions where these concepts exist in national legislation; in all cases the interests of the children shall be paramount; The same personal rights as husband and wife, including the right to choose a family name, a profession and an occupation; The same rights for both spouses in respect of the ownership, acquisition, management, administration, enjoyment and disposition of property, whether free of charge or for a valuable consideration. Second. The betrothal and the marriage of a child shall have no legal effect, and all necessary action, including legislation, shall be taken to specify a minimum age for marriage and to make the registration of marriages in an official registry compulsory."

With regards to the article 11, Malaysia interprets the provisions of this article as a reference to the prohibition of discrimination on the basis of equality between men and women only. The provision reads as "First. States Parties shall take all appropriate measures to eliminate discrimination against women in the field of employment in order to ensure, on a basis of equality of men and women, the same rights, in particular:

The right to work as an inalienable right of all human beings; The right to the same employment opportunities, including the application of the same criteria for selection in matters of employment; The right to free choice of profession and employment, the right to promotion, job security and all benefits and conditions of service and the right to receive vocational training and retraining, including apprenticeships, advanced vocational training and recurrent training; The right to equal remuneration, including benefits, and to equal treatment in respect of work of equal value, as well as equality of treatment in the evaluation of the quality of work; The right to social security, particularly in cases of retirement, unemployment, sickness, invalidity and old age and other incapacity to work, as well as the right to paid leave; The right to protection of health and to safety in working conditions, including the safeguarding of the function of reproduction.

Second, in order to prevent discrimination against women on the grounds of marriage or maternity and to ensure their effective right to work, States Parties shall take appropriate measures:

To prohibit, subject to the imposition of sanctions, dismissal on the grounds of pregnancy or of maternity leave and discrimination in dismissals on the basis of marital status; To introduce maternity leave with pay or with comparable social benefits without loss of former employment, seniority or social allowances; To encourage the provision of the necessary supporting social services to enable parents to combine family obligations with work responsibilities and participation in public life, in particular through promoting the establishment and development of a network of child-care facilities; To provide special protection to women during pregnancy in types of work proved to be harmful to them.

last, Protective legislation relating to matters covered in this article shall be reviewed periodically in the light of scientific and technological knowledge and shall be revised, repealed or extended as necessary."

Later in 1998, Malaysia made a partial withdrawal in respect of articles 2 (f), 9(1), 16(1)(b), (d) (e) and (h). Due to urgement made by the non-governmental bodies relating to women's human rights group,Malaysia in 2010 has withdraw its reservations to the articles 5(a), 7(b) and 16(2). However, the reservations remain on the five CEDAW provisions Article 9 (2), 16 (1)(a), (f), (e) and (g).

It is important to higlight that the Convention provides the basis for realizing equality between women and men through ensuring women's equal access to, and equal opportunities in, political and public life. States parties may agree to some provisions and vary to another. They also may agree to take all measures in order to ensure that women can enjoy their fundamental freedoms and human rights.

The states are actually legally bound to the Convention once they ratifies it. However, full implementation of the provisions should have some limitations. Malaysia for example made the reservations because it is a state which is very complex with various of class of society from different cultural and religious background. The implementation of CEDAW in Malaysia with some reservations is needed to meet with the needs of those society. Here, it can be said that the provisions in CEDAW is quite redundant with the provisions of rights and maintenance of women under Islamic Law. On the other hand, it is believe that Islamic Law always gift best protection over women and children. 


\section{CONCLUSION}

The purpose of this paper is to address that religion is important factor that always being overlooked. As regards to the islamic states like malaysia, maqasid al-syariah is one of the essential that may be taken into consideration in ratifying each and every international treaty. Maqasid al syariah may be used as a benchmark or guideline before the treaty being signed and enforced in state level.

If religion for example Islamic Law has been taken into account there will be no articles which is in contravention of the law. No right of people may be infringed if religion been taken into consideration. For example, as for Malaysia in ratifying CEDAW may take into account the objectives of Islamic Law as to protect the right of the women from the angle of religion along with human's right.

The reservatins made by malaysia regarding the said articles show that the convention is infringing the Islamic law. That is the proof of the need of religion in international treaty. Maqasid al syariah or principles of islamic law which is related to women is in protection of life and linage. It is true that woman is being violated but from the side of islam some said "violation" is not violation at all.

In addition, the purpose of having maqasid al-syariah as a parameter is to ensure the purpose of the convention meet with the purpose of islam and not made to satisfy human merely. If it is brings benefit to the religion and the people within it will be more advantagous. It is not necessarily modern world may reject religion in all occurence but the religion itself may be the borderline for people nowadays to live in peace and harmony.

It can be concluded that, the maqasid al shariah is a potential instrument for Islamic countries' foreign relations vis-à-vis international treaty. It can be a new parameter to be observed by Islamic countries before giving the consent to be bound by international treaty.The parameter will be developed as one of the important guidelines for Islamic countries in giving their consent, reservation or objection to the provisions in any international treaty. The principles of Maqasid al shariah is a weapon to scrutinize the international human rights treaty in order to ensure no terms being made prejudicial to the rights of human.

Besides that, a state shall not go beyond the good intention in making foreign policy with the existence of this parameter. It will uphold the virtue of Islamic law in a Islamic state like Malaysia. Once maqasid-al-shariah is set up as a parameter each and every international treaty that going to be ratified or made by our country must be based on that parameter. For example, the latest signed transpacific partnership act, Malaysia should review it under the parameter before ratify and sign it if it is meet with the intention of protection of property with the economical advantages and it is certain to ratify it and otherwise. That is how the parameter should act and not to burden the state.

\section{REFERENCE}

[1] Majma' al-Lughah al-Arabiyyah(2004). Mu'jam alWasit. Cairo: Maktabah al-Shuruq al-Dauliah, $4^{\text {th }}$ edi.

[2]

asser .(2008). Maqasid Al-Shari'ah As Philosophy of Islamic Law: A System Approach. Washington: International Institute of Islamic Thought.

[3] Al-Qaradhawi, Y.(2012). Dirasatun Fi FiqhMaqasid al-Shariah. Cairo: Dar al-Shorouk.

[4] Mohamad .A (2006) Islamic Law An Introduction Gombak: Iium Press

[5] Sya'bani A. (2015) Maqasid Al-Syari'ah Sebagai Metode Ijtihad Mataram: Institut Agama Islam Negeri (IAIN)

[6] Muhammad. (2007). Al-Maqasid l-Shariahwa Atharuha fi al-Fiqh al-Islami. Cairo:Darul Hadith.

[7] Lafortune M.D. (2013) International Law And Foreign Policy: A Mutual Influence 